\title{
Vitamin D and Multiple Sclerosis
}

\author{
Anita Raghuwanshi, Sneha S. Joshi, and Sylvia Christakos* \\ Department of Biochemistry and Molecular Biology, UMDNJ-New Jersey Medical School, 185 \\ South Orange Ave. Newark, NJ 07103 USA
}

\begin{abstract}
Vitamin D is a principal regulator of calcium homeostasis. However, recent evidence has indicated that vitamin D can have numerous other physiological functions including inhibition of proliferation of a number of malignant cells including breast and prostate cancer cells and protection against certain immune mediated disorders including multiple sclerosis (MS). The geographic incidence of MS indicates an increase in MS with a decrease in sunlight exposure. Since vitamin D is produced in the skin by solar or UV irradiation and high serum levels of 25hydroxyvitamin $\mathrm{D}(25(\mathrm{OH}) \mathrm{D})$ have been reported to correlate with a reduced risk of MS, a protective role of vitamin $\mathrm{D}$ is suggested. Mechanisms whereby the active form of vitamin $\mathrm{D}$, 1,25-dihydroxyvitamin $\mathrm{D}_{3}\left(1,25(\mathrm{OH})_{2} \mathrm{D}_{3}\right)$ may act to mediate this protective effect are reviewed. Due to its immunosuppressive actions, it has been suggested that $1,25(\mathrm{OH})_{2} \mathrm{D}_{3}$ may prevent the induction of MS.
\end{abstract}

\section{Keywords}

Vitamin D; Sunlight; Multiple Sclerosis; Immune Function; 1,25-Dihdyroxyvitamin $\mathrm{D}_{3}$; Review

\section{INTRODUCTION}

Multiple sclerosis (MS) is an inflammatory, demyelinating and neurodegenerative disease of the central nervous system (Fontoura et al., 2006). While the exact etiology of MS remains unknown, it is thought that many different genetic as well as environmental factors play a role (Hauser and Oksenberg, 2006). Numerous epidemiological studies have indicated a negative correlation between increased sun exposure, which would result in a greater vitamin $\mathrm{D}$ synthetic rate, and diets rich in vitamin $\mathrm{D}$ (fortified dairy products and fish oils) and MS prevalence (Freedman et al., 2000; Goldberg, 1974; Kurtzke, 1967; Kurtzke, 2000; van der Mei et al., 2001). For example, MS is, for the most part, unknown in equatorial regions. The prevalence of MS increases with latitude. In Norway, although there is high MS prevalence inland, on the Norwegian coast, where there is high fish consumption, there is lower prevalence of MS. The mechanisms by which vitamin D may decrease the risk for MS, which have been suggested to involve normalization of the T-cell response, are only now beginning to be defined.

\section{VITAMIN D}

\section{Vitamin D metabolism and mechanism of action}

Vitamin $\mathrm{D}_{3}$ (cholecalciferol) is taken in the diet or is synthesized in the skin from 7dehydrocholesterol by ultraviolet irradiation. For biological activity vitamin D must be

Address correspondence to Dr. Sylvia Christakos, Dept. of Biochemistry and Molecular Biology, UMDNJ-New Jersey Medical School, 185 South Orange Ave, Newark, NJ 07103, Tel: 973-972-4033, Fax: 973-972-5594, christak@umdnj.edu. 
converted to its active form. Vitamin D is transported in the blood by the vitamin D binding protein (DBP; a specific binding protein for vitamin D and its metabolites in the serum) to the liver where it is hydroxylated by the 25-hydroxylase enzyme resulting in the formation of 25-hydroxyvitamin $\mathrm{D}_{3}\left(25(\mathrm{OH}) \mathrm{D}_{3}\right)$, the major circulating form of vitamin $\mathrm{D}$. $25(\mathrm{OH}) \mathrm{D}_{3}$ is transported by the DBP to the kidney. In the proximal convoluted and straight tubules of the kidney $25(\mathrm{OH}) \mathrm{D}_{3}$ is converted to the hormonally active form of vitamin $\mathrm{D} 1,25$ dihydroxyvitamin $\mathrm{D} 3\left(1,25(\mathrm{OH})_{2} \mathrm{D}_{3}\right)$ by the 25-hydroxyvitamin $\mathrm{D}_{3}$ 1-alpha-hydroxylase enzyme (1- alpha(OH)ase (Christakos et al., 2003; DeLuca, 2004; Sutton and MacDonald, 2003). Besides the proximal tubule of the kidney, placenta and macrophages are also sites of synthesis of 1- alpha $(\mathrm{OH})$ ase. The presence of 1-alpha $(\mathrm{OH})$ ase and the role for the local production of $1,25(\mathrm{OH})_{2} \mathrm{D}_{3}$ in the function of additional cell types are still a matter of debate. Although the phenotype of the 1- alpha( $\mathrm{OH})$ ase null mutant mice is identical to human vitamin $\mathrm{D}$ dependent rickets type $\mathrm{I}$, it is of interest that immune dysfunction has also been noted in these mice, suggesting local production of $1,25(\mathrm{OH})_{2} \mathrm{D}_{3}$ in cells in the immune system (Panda et al., 2001). In an auto-regulatory mechanism $1,25(\mathrm{OH})_{2} \mathrm{D}_{3}$ induces its own degrading enzyme, 25-hydroxyvitamin $\mathrm{D}_{3}$ 24-hydroxylase (24(OH)ase), thereby preventing vitamin $\mathrm{D}$ toxicity. $1,25(\mathrm{OH})_{2} \mathrm{D}_{3}$ is a principal factor that regulates calcium and phosphate homeostasis. The classical target tissues are bone, kidney and intestine. However, $1,25(\mathrm{OH})_{2} \mathrm{D}_{3}$ has been reported to have numerous other physiological functions including inhibition of proliferation of a number of malignant cell, including breast and prostate cancer cells, effects on epidermal differentiation and effects on differentiation and function of cells in the immune system. $1,25(\mathrm{OH})_{2} \mathrm{D}_{3}$, similar to other steroid hormones, regulates gene expression in target cells by binding stereospecifically to a high affinity, low capacity nuclear receptor (vitamin D receptor or VDR) resulting in the concentration of the $1,25(\mathrm{OH})_{2} \mathrm{D}_{3}$ receptor complex in the nucleus and the activation or repression of target genes. Liganded VDR acts as a heterodimer with the retinoid X receptor (RXR), binds to vitamin D response elements (VDREs) within the promoter of target genes and, together with coactivators, affects target gene transcription (Christakos et al., 2003; DeLuca, 2004; Rachez and Freedman, 2000; Rachez et al., 1999; Sutton and MacDonald, 2003), Coactivators include the p160 coactivators, SRC-1, SRC-2 and SRC-3 that have histone acetylase (HAT) activity. The HAT activity of the p160 coactivators is thought to destabilize the interaction between DNA and the histone core, liberating DNA for transcription. Recent studies have indicated that cooperativity between histone methyltransferases and p160 coactivators may also play a fundamental role in VDR mediated transcriptional activation (Christakos et al., 2007). VDR mediated transcription is also mediated by the coactivator complex DRIP (vitamin D receptor interacting protein (Christakos et al., 2003; Rachez and Freedman, 2000; Rachez et al., 1999). This complex functions by recruitment of RNA polymerase II. It has been suggested that cell and promoter specific functions of VDR may be mediated through differential recruitment of coactivators.

\section{Sunlight and vitamin D sufficiency}

Total body sun exposure can provide an equivalent of 10,000 IU vitamin D per day (Holick, 1995; Holick, 2002). However, the vitamin $D_{3}$ produced from 7-dehydrocholesterol depends on the intensity of UV irradiation which varies with latitude and season. For example in San Juan (18deg $\mathrm{N}$ ) the skin produces vitamin $\mathrm{D}_{3}$ all year. In Boston (42.2deg N) no vitamin $\mathrm{D}$ is produced from sun exposed skin from November to February and in Edmonton (52deg N) none is produced from October until April (Webb et al., 1988). Clothing as well as sunscreen have been reported to prevent the conversion of 7-dehydrocholesterol to vitamin $\mathrm{D}_{3}$ in the covered areas (Matsuoka et al., 1987; Matsuoka et al., 1992). Serum 25(OH) $\mathrm{D}_{3}$ levels, the most reliable indicator of vitamin D sufficiency, have been shown to vary with sunlight levels (there is a two month lag period between the highest and lowest level of sunlight and the respective peak and troughs in $25(\mathrm{OH}) \mathrm{D}_{3}$ levels) (Hine and Roberts, 1994; 
Holick, 2002). Although there is still some controversy as to the normal and optimal blood levels of $25(\mathrm{OH}) \mathrm{D}_{3}$, most experts define vitamin $\mathrm{D}$ deficiency as levels of $25(\mathrm{OH}) \mathrm{D}_{3}$ below $30 \mathrm{ng} / \mathrm{ml}$ (Holick, 2007). With this definition, a significant proportion of the world's population is vitamin $\mathrm{D}$ deficient. Due to the concerns regarding the association of sunlight and skin cancer and when enough sunlight is not available, vitamin D supplements are recommended. The general consensus is that the current recommended dosage $400 \mathrm{IU}$ is inadequate (Vieth, 1999). It is estimated that 1,000 IU vitamin D3/day is needed to maintain $25(\mathrm{OH}) \mathrm{D}_{3}$ level at the desired level (Heaney et al., 2003). It has been reported that vitamin D toxicity with hypercalcemia has not been observed at doses lower than 10,000 IU per day (Hathcock et al., 2007).

\section{VITAMIN D AND IMMUNE FUNCTION}

\section{Mechanism of vitamin D action in the immune system}

Early studies indicating the presence of VDR in activated T-cells led to the suggestion that $1,25(\mathrm{OH})_{2} \mathrm{D}_{3}$ may play a role in the regulation of the immune response. $1,25(\mathrm{OH})_{2} \mathrm{D}_{3}$ can inhibit T-lymphocyte proliferation and activation (Bhalla et al., 1983). This immunosuppressive effect is correlated with a decrease in IL-2 mRNA (one of the first genes to be expressed post activation) as well as with a decrease in IFN-gamma and GMCSF mRNA levels (Bhalla et al., 1986; Reichel et al., 1987; Rigby, 1988; Tobler et al., 1987). For IL-2, IFN-gamma and GM-CSF, it has been reported that the mechanism involves VDR mediated inhibition of gene transcription (Alroy et al., 1995; Cippitelli and Santoni, 1998; Towers and Freedman, 1998). The mechanism of the transcriptional repression of the human IL-2 gene by $1,25(\mathrm{OH})_{2} \mathrm{D}_{3}$ involves block of the formation of the NFATp/AP-1 complex by the VDR/RXR heterodimer and stable association of VDR/RXR with the NFAT1 element in the IL-2 promoter (Alroy et al., 1995). For inhibition of GMCSF, VDR binds to the GM550 element that contains binding sites for NFAT1, Jun and Fos. Unlike the mechanism of IL-2 repression, VDR binds to this element as a monomeric species, independent of RXR. VDR competes with NFAT for binding to the composite site, positioning itself adjacent to Jun-Fos, stabilizing the Jun-Fos complex (Towers and Freedman, 1998). The selective interaction is between VDR and c-Jun (Fig. 1). Overexpression of c-Jun but not c-Fos is able to rescue the VDR repression. For GM-CSF repression, the model is that VDR would lock AP-1 in an off state. For the repression of IFN-gamma transcription, direct binding of VDR/RXR to a silencer region BED $(-212 /-183)$ in the human IFN-gamma promoter was suggested (Cippitelli and Santoni, 1998). 1,25(OH $)_{2} \mathrm{D}_{3}$ has also been reported to up-regulate IL-4 under non-polarizing conditions (Cantorna et al., 1998b). In addition, $1,25(\mathrm{OH})_{2} \mathrm{D}_{3}$ has been shown to inhibit the differentiation and survival of dendritic cells, resulting in impaired alloreactive T-cell activation (Griffin et al., 2001; Penna and Adorini, 2000). The inhibition of maturation and differentiation of dendritic cells results in a decrease in IL-12 and an increase in IL-10 secretion (Penna and Adorini, 2000). The repressive effect of $1,25(\mathrm{OH})_{2} \mathrm{D}_{3}$ on IL-12 production was reported to be at the level of transcription and required binding of the VDR/ RXR heterodimer to the binding site for NF-kappaB in the IL-12 p40 promoter (p40-kB) (D'Ambrosio et al., 1998). It is possible that the effects of $1,25(\mathrm{OH})_{2} \mathrm{D}_{3}$ on IL-10, IL-4 and perhaps other cytokines may be also be indirect, resulting from an effect of $1,25(\mathrm{OH})_{2} \mathrm{D}_{3}$ on other cells and genes resulting in a net change in cytokine expression.

Recent studies have indicated that $1,25(\mathrm{OH})_{2} \mathrm{D}_{3}$ regulates not only adaptive but also innate immunity. $1,25(\mathrm{OH})_{2} \mathrm{D}_{3}$ has been shown to induce the antimicrobial peptide cathelicidin with subsequent killing of bacteria including mycobacterium tuberculosis (Liu et al., 2007). Thus, with regard to innate immunity, $1,25(\mathrm{OH})_{2} \mathrm{D}_{3}$ may promote the host's response to a pathogen. The effect on adaptive immunity, on the other hand, may limit the immune response and may function in a process representative of tolerance. 


\section{Autoimmune diseases and vitamin D}

Previous studies have indicated that $1,25(\mathrm{OH})_{2} \mathrm{D}_{3}$ can at least partially protect against a number of experimental autoimmune diseases. The experimental autoimmune diseases suppressed by $1,25(\mathrm{OH})_{2} \mathrm{D}_{3}$ include experimental allergic encephalitis (EAE, the murine model of multiple sclerosis), experimental lupus erythematosus and autoimmune thyroiditis (Abe et al., 1990; Fournier et al., 1990; Lemire and Archer, 1991). 1,25(OH) ${ }_{2} \mathrm{D}_{3}$ has also been reported to prevent the progression of arthritis in murine models of human arthritis (infection of mice with Borrelia burgdorferi or immunization of mice with type II collagen) (Cantorna et al., 1998a). 1,25(OH) ${ }_{2} \mathrm{D}_{3}$ was also effective in collagen induced arthritis in inhibiting progression of arthritis when given to mice with early symptoms (Cantorna et al., 1998a).

In addition, $1,25(\mathrm{OH})_{2} \mathrm{D}_{3}$ prevents autoimmune diabetes in nonobese diabetic (NOD) mice (Mathieu et al., 1994). In the NOD mouse model and in the EAE model, it has been reported that an analog of 1,25(OH) ${ }_{2} \mathrm{D}_{3}, 1,25$-dihydroxy-16,23Z-diene-26,27-hexafluoro-19-norvitamin $\mathrm{D}_{3}$ and $1,25(\mathrm{OH})_{2} \mathrm{D}_{3}$ respectively are effective not only in preventing the induction of the disease but also in inhibiting its progression when administered after disease onset (Cantorna et al., 1996; Gregori et al., 2002).

\section{VITAMIN D AND MULTIPLE SCLEROSIS}

\section{Incidence of multiple sclerosis varies with sunlight}

Numerous epidemiological studies have reported a negative correlation between exposure to sunlight and sufficient dietary vitamin $\mathrm{D}_{3}$ intake and prevalence of MS (Freedman et al., 2000; Goldberg, 1974; Kurtzke, 1967; Kurtzke, 2000; van der Mei et al., 2001). MS prevalence was shown to vary not only with latitude but also with altitude (Kurtzke, 1967). There is lower MS incidence at high altitudes that corresponds to more optimal solar irradiation and increased cutaneous vitamin D synthesis. Also, it has been reported that immigrants, particularly if they move before the age of 15, acquire the MS risk of their new homeland, supporting the concept that early intervention to maintain vitamin D sufficiency may have a protective role against MS (Hammond et al., 2000; Pugliatti et al., 2002; van der Mei et al., 2003).

\section{$1,25(\mathrm{OH})_{2} \mathrm{D}_{3}$ inhibits $\mathrm{EAE}$}

Although numerous studies have shown that $1,25(\mathrm{OH})_{2} \mathrm{D}_{3}$ inhibits EAE, the precise mechanisms involved have not been clearly defined and have been a matter of debate. $1,25(\mathrm{OH})_{2} \mathrm{D}_{3}$ was found to inhibit EAE in mice lacking CD8+ T-cells but not in Rag-1 null mice (Meehan and DeLuca, 2002; Nashold et al., 2001). The findings in the Rag-1 null mice suggest that $1,25(\mathrm{OH})_{2} \mathrm{D}_{3}$ acts through a Rag-1 dependent cell to limit the occurrence of Th1 activation in the CNS. It has been suggested that CD4+ T-cells are a target of $1,25(\mathrm{OH})_{2} \mathrm{D}_{3}$ immunosuppression in EAE and that $1,25(\mathrm{OH})_{2} \mathrm{D}_{3}$ may sensitize $\mathrm{CD} 4+\mathrm{T}$ cells to apoptotic stimuli (Pedersen et al., 2007). Both an increase and no change in IL-4 in lymph nodes in EAE after $1,25(\mathrm{OH})_{2} \mathrm{D}_{3}$ treatment have been reported (Cantorna et al., 1998b; Nashold et al., 2001). In response to $1,25(\mathrm{OH})_{2} \mathrm{D}_{3}$, a reduction and no change in interferon gamma have been described (Muthian et al., 2006; Nashold et al., 2001). The lack of consistency may be due to both indirect and direct effects of $1,25(\mathrm{OH})_{2} \mathrm{D}_{3}$. Further studies need to be done to differentiate between these effects. With regard to IL-4, using IL-4 KO mice it has been reported that EAE is more severe in the absence of IL-4 and IL-4 $\mathrm{KO}$ mice are resistant to $1,25(\mathrm{OH})_{2} \mathrm{D}_{3}$ treatment (Cantorna et al., 2000). $1,25(\mathrm{OH})_{2} \mathrm{D}_{3}$ is also unable to inhibit EAE in IL-10 or IL-10 receptor KO mice, suggesting IL-10 dependent protective effects of $1,25(\mathrm{OH})_{2} \mathrm{D}_{3}$ (Spach et al., 2006). It has also been reported that in vivo 
treatment with $1,25(\mathrm{OH})_{2} \mathrm{D}_{3}$ or $1,25(\mathrm{OH})_{2} \mathrm{D}_{3}$ analog inhibits EAE in association with inhibition of IL-12 (Mattner et al., 2000).

Gender differences have also been noted in the effect of $1,25(\mathrm{OH})_{2} \mathrm{D}_{3}$ or vitamin D on EAE. It has been reported that higher concentrations of $1,25(\mathrm{OH})_{2} \mathrm{D}_{3}$ are needed to prevent EAE in male mice compared to female mice (Cantorna et al., 1999). In addition, it was found that 5 micrograms/day of vitamin $\mathrm{D}_{3}$ significantly inhibited EAE in female but not male mice (Spach and Hayes, 2005). In ovariectomized mice the protective effect of vitamin D was not observed. In the vitamin D study both male and female mice had equivalent levels of serum $1,25(\mathrm{OH})_{2} \mathrm{D}_{3}$ (Spach and Hayes, 2005). Further studies examining mechanisms involved in the gender differences in the response to $1,25(\mathrm{OH})_{2} \mathrm{D}_{3}$ or vitamin $\mathrm{D}_{3}$ are needed.

It has been suggested that the effects of $1,25(\mathrm{OH})_{2} \mathrm{D}_{3}$ or vitamin $\mathrm{D}$ could include effects in the CNS. However, it should be noted, when suggesting central effects of $1,25(\mathrm{OH})_{2} \mathrm{D}_{3}$, that $1,25(\mathrm{OH})_{2} \mathrm{D}_{3}$ receptors are present in low levels in the brain and have a very localized distribution in the CNS (Stumpf and O'Brien, 1987; Stumpf et al., 1982). 1,25(OH) ${ }_{2} \mathrm{D}_{3}$ sites of action have been identified by autoradiography within certain structures in the forebrain, hindbrain and spinal cord (Stumpf et al., 1988). The central nucleus of the amygdala and the bed nucleus of the stria terminalis have the densest accumulation of $1,25(\mathrm{OH})_{2} \mathrm{D}_{3}$. In the spinal cord nuclear retention of $1,25(\mathrm{OH})_{2} \mathrm{D}_{3}$ is strongest in motor neurons in lamina IX. Nuclear retention is also observed in neurons of lamina II, VIII and X and in cells in the caudal spinal trigeminal nucleus. Immunocytochemical studies are generally in agreement with the autoradiographic findings (Prufer et al., 1999). Also, restricted transport of vitamin D metabolites to the brain has been reported, at least in wild type rodent brain. Unlike estrogens, in which the protein steroid complex freely enters the brain, it has been reported that the vitamin $\mathrm{D}$ serum binding protein limits access of $1,25(\mathrm{OH})_{2} \mathrm{D}_{3}$ into the CNS (Gascon-Barre and Huet, 1983). In addition, although it has been suggested that $1,25(\mathrm{OH})_{2} \mathrm{D}_{3}$ could be synthesized from $25(\mathrm{OH}) \mathrm{D}_{3}$ in the CNS and thus could account for observed effects of vitamin $\mathrm{D}$, it should be noted that the presence of 1-alpha-(OH)ase at sites other than kidney, placenta and macrophages is a matter of debate (Shultz et al., 1983).

The role of calcium in the $1,25(\mathrm{OH})_{2} \mathrm{D}_{3}$ suppressive effects in EAE also needs to be considered. Low calcium diets have been reported to result in resistance to treatment with $1,25(\mathrm{OH})_{2} \mathrm{D}_{3}$ and it was found that calcium is required for the suppressive effect in EAE (Cantorna et al., 2000). It is of interest that in the lupus model MRL/1 mice, low calcium plus $1,25(\mathrm{OH})_{2} \mathrm{D}_{3}$ accelerated SLE while mice on the normal calcium $(0.87 \%)$ diet showed reduced SLE with $1,25(\mathrm{OH})_{2} \mathrm{D}_{3}$ treatment (DeLuca and Cantorna, 2001). In addition, inflammatory bowel disease (IBD) is prevented by $1,25(\mathrm{OH})_{2} \mathrm{D}_{3}$ administration also under conditions of normal calcium (DeLuca and Cantorna, 2001). Unlike EAE, SLE and IBD, $1,25(\mathrm{OH})_{2} \mathrm{D}_{3}$ can prevent collagen induced arthritis under low dietary calcium conditions (Cantorna et al., 1996; DeLuca and Cantorna, 2001). Thus low calcium results in resistance to $1,25(\mathrm{OH})_{2} \mathrm{D}_{3}$ in some but not all autoimmune diseases. These studies should help in the design of analogs that will be effective in vivo. It has recently been reported that the combination of the $1,25(\mathrm{OH})_{2} \mathrm{D}_{3}$ analog TX527 with interferon beta resulted in protection against EAE that was more effective than each treatment alone, suggesting consideration of a combination treatment for clinical intervention in MS (van Etten et al., 2007).

\section{Does vitamin $D$ or $1,25(\mathrm{OH})_{2} \mathrm{D}_{3}$ analog have clinical potential for MS?}

Although the effects of $1,25(\mathrm{OH})_{2} \mathrm{D}_{3}$ in the EAE model are suggestive, the question that remains is whether vitamin $\mathrm{D}_{3}$ or $1,25(\mathrm{OH})_{2} \mathrm{D}_{3}$ analogs have clinical potential. A number of studies have shown that high serum levels of $25(\mathrm{OH}) \mathrm{D}_{3}$ are associated with a decreased risk of MS. The largest of these trials by Munger et al in 2006 searched the US Army and Navy databases and found 257 cases of military personnel with diagnosed MS and stored serum 
available for testing of $25(\mathrm{OH}) \mathrm{D}_{3}$ levels (Munger et al., 2006). A case matched analysis using 514 matched controls showed that MS incidence was lower in samples from 148 subjects with the highest circulating levels of $25(\mathrm{OH}) \mathrm{D}_{3}$. The inverse relationship between $25(\mathrm{OH}) \mathrm{D}_{3}$ levels and MS was particularly strong for $25(\mathrm{OH}) \mathrm{D}_{3}$ levels measured before age 20 , suggesting that vitamin D supplements in adolescents and young adults, particularly those who are at high risk for MS (with a family history, for example), may have protective benefit. A protective effect of cod liver oil and regular fish consumption has also been reported (Kampman et al., 2007). A large clinical trial will be required to determine whether vitamin $\mathrm{D}$ or analog, alone or in combination with known treatments, is not only protective but is also effective in patients with active MS. A better understanding of the mechanisms by which $1,25(\mathrm{OH})_{2} \mathrm{D}_{3}$ acts to affect the immune system is needed in order to aid in the design of $1,25(\mathrm{OH})_{2} \mathrm{D}_{3}$ analogs with clinical potential for MS.

\section{CONCLUSION}

For individuals predisposed to MS, evidence indicates that maintenance of adequate vitamin $\mathrm{D}$ has a protective effect. One mechanism of vitamin $\mathrm{D}$ action may be to maintain balance in the T-cell response and thus avoid autoimmunity. Further studies are needed with regard to mechanisms involved in $1,25(\mathrm{OH})_{2} \mathrm{D}_{3}$ mediated immune regulation and to determine whether vitamin $\mathrm{D}$ or analog, alone or in combination with other treatments, is not only protective but is also effective in patients with active MS.

\section{Acknowledgments}

Studies referenced from the laboratory of S Christakos were supported in part by NIH grant DK38961 to S.C.

\section{Abbreviations}

MS

EAE

SLE

IBD

CNS

DNA

RNA

NFAT

NF-kappaB

IL-2

IL-4

IL-10

IL-12

GM-CSF

DRIP

HAT

VDR multiple sclerosis

experimental allergic encephalitis

systemic lupus erythematosus

inflammatory bowel disease

central nervous system

deoxyribonucleic acid

ribonucleic acid

nuclear factor of activated T-cells

nuclear factor kappa B

interleukin 2

interleukin 4

interleukin 10

interleukin 12

granulocyte macrophage colony stimulating factor

vitamin D receptor interacting protein complex

histone acetylase

vitamin D receptor 


$\begin{array}{ll}\text { RXR } & \text { retinoid X receptor } \\ \text { VDRE } & \text { vitamin D response element } \\ \text { 1-alpha-(OH)ase } & \text { 25-hydroxyvitamin D3 1-alpha-hydroxylase } \\ \mathbf{2 4}(\mathbf{O H}) \text { ase } & \text { 25-hydroxyvitamin D3 24-hydroxylase } \\ \mathbf{2 5}(\mathbf{O H}) \mathbf{D}_{3} & \text { 25-hydroxyvitamin D3 } \\ \mathbf{1 , 2 5}(\mathbf{O H})_{\mathbf{2}} \mathbf{D}_{\mathbf{3}} & \text { 1,25-dihydroxyvitamin D3 } \\ \mathbf{K O} & \text { knock out } \\ \mathbf{U V} & \text { ultraviolet }\end{array}$

\section{References}

1. Abe J, Nakamura K, Takita Y, Nakano T, Irie H, Nishii Y. Prevention of immunological disorders in MRL/l mice by a new synthetic analogue of vitamin D3: 22-oxa-1 alpha,25-dihydroxyvitamin D3. J Nutr Sci Vitaminol (Tokyo). 1990; 36:21-31. [PubMed: 2163440]

2. Alroy I, Towers TL, Freedman LP. Transcriptional repression of the interleukin-2 gene by vitamin D3: direct inhibition of NFATp/AP-1 complex formation by a nuclear hormone receptor. Mol Cell Biol. 1995; 15:5789-99. [PubMed: 7565732]

3. Bhalla AK, Amento EP, Clemens TL, Holick MF, Krane SM. Specific high-affinity receptors for 1,25-dihydroxyvitamin D3 in human peripheral blood mononuclear cells: presence in monocytes and induction in T lymphocytes following activation. J Clin Endocrinol Metab. 1983; 57:1308-10. [PubMed: 6313738]

4. Bhalla AK, Amento EP, Krane SM. Differential effects of 1,25-dihydroxyvitamin D3 on human lymphocytes and monocyte/macrophages: inhibition of interleukin-2 and augmentation of interleukin-1 production. Cell Immunol. 1986; 98:311-22. [PubMed: 3489547]

5. Cantorna MT, Hayes CE, DeLuca HF. 1,25-Dihydroxyvitamin D3 reversibly blocks the progression of relapsing encephalomyelitis, a model of multiple sclerosis. Proc Natl Acad Sci U S A. 1996; 93:7861-4. [PubMed: 8755567]

6. Cantorna MT, Hayes CE, DeLuca HF. 1,25-Dihydroxycholecalciferol inhibits the progression of arthritis in murine models of human arthritis. J Nutr. 1998a; 128:68-72. [PubMed: 9430604]

7. Cantorna MT, Humpal-Winter J, DeLuca HF. Dietary calcium is a major factor in 1,25dihydroxycholecalciferol suppression of experimental autoimmune encephalomyelitis in mice. $\mathrm{J}$ Nutr. 1999; 129:1966-71. [PubMed: 10539770]

8. Cantorna MT, Humpal-Winter J, DeLuca HF. In vivo upregulation of interleukin-4 is one mechanism underlying the immunoregulatory effects of 1,25-dihydroxyvitamin $\mathrm{D}(3)$. Arch Biochem Biophys. 2000; 377:135-8. [PubMed: 10775452]

9. Cantorna MT, Woodward WD, Hayes CE, DeLuca HF. 1,25-dihydroxyvitamin D3 is a positive regulator for the two anti-encephalitogenic cytokines TGF-beta 1 and IL-4. J Immunol. 1998b; 160:5314-9. [PubMed: 9605130]

10. Christakos S, Dhawan P, Benn B, Porta A, Hediger M, Oh GT, Jeung EB, Zhong Y, Ajibade D, Dhawan K, Joshi S. Vitamin D: molecular mechanism of action. Ann N Y Acad Sci. 2007; 1116:340-8. [PubMed: 18083936]

11. Christakos S, Dhawan P, Liu Y, Peng X, Porta A. New insights into the mechanisms of vitamin D action. J Cell Biochem. 2003; 88:695-705. [PubMed: 12577303]

12. Cippitelli M, Santoni A. Vitamin D3: a transcriptional modulator of the interferon-gamma gene. Eur J Immunol. 1998; 28:3017-30. [PubMed: 9808170]

13. D’Ambrosio D, Cippitelli M, Cocciolo MG, Mazzeo D, Di Lucia P, Lang R, Sinigaglia F, PaninaBordignon P. Inhibition of IL-12 production by 1,25-dihydroxyvitamin D3. Involvement of NFkappaB downregulation in transcriptional repression of the p40 gene. J Clin Invest. 1998; 101:252-62. [PubMed: 9421488] 
14. DeLuca HF. Overview of general physiologic features and functions of vitamin D. Am J Clin Nutr. 2004; 80:1689S-96S. [PubMed: 15585789]

15. DeLuca HF, Cantorna MT. Vitamin D: its role and uses in immunology. FASEB J. 2001; 15:257985. [PubMed: 11726533]

16. Fontoura P, Steinman L, Miller A. Emerging therapeutic targets in multiple sclerosis. Curr Opin Neurol. 2006; 19:260-6. [PubMed: 16702832]

17. Fournier C, Gepner P, Sadouk M, Charreire J. In vivo beneficial effects of cyclosporin A and 1,25dihydroxyvitamin D3 on the induction of experimental autoimmune thyroiditis. Clin Immunol Immunopathol. 1990; 54:53-63. [PubMed: 2293907]

18. Freedman DM, Dosemeci M, Alavanja MC. Mortality from multiple sclerosis and exposure to residential and occupational solar radiation: a case-control study based on death certificates. Occup Environ Med. 2000; 57:418-21. [PubMed: 10810132]

19. Gascon-Barre M, Huet PM. Apparent [3H]1,25-dihydroxyvitamin D3 uptake by canine and rodent brain. Am J Physiol. 1983; 244:E266-71. [PubMed: 6687510]

20. Goldberg P. Multiple sclerosis: vitamin D and calcium as environmental determinants of prevalence; (A viewpoint) part 1: sunlight, dietary factors and epidemiology. Int J Environ Stud. 1974; 6:19-27.

21. Gregori S, Giarratana N, Smiroldo S, Uskokovic M, Adorini L. A 1alpha,25-dihydroxyvitamin $\mathrm{D}(3)$ analog enhances regulatory T-cells and arrests autoimmune diabetes in NOD mice. Diabetes. 2002; 51:1367-74. [PubMed: 11978632]

22. Griffin MD, Lutz W, Phan VA, Bachman LA, McKean DJ, Kumar R. Dendritic cell modulation by 1alpha,25 dihydroxyvitamin D3 and its analogs: a vitamin D receptor-dependent pathway that promotes a persistent state of immaturity in vitro and in vivo. Proc Natl Acad Sci U S A. 2001; 98:6800-5. [PubMed: 11371626]

23. Hammond SR, English DR, McLeod JG. The age-range of risk of developing multiple sclerosis: evidence from a migrant population in Australia. Brain. 2000; 123(Pt 5):968-74. [PubMed: 10775541]

24. Hathcock JN, Shao A, Vieth R, Heaney R. Risk assessment for vitamin D. Am J Clin Nutr. 2007; 85:6-18. [PubMed: 17209171]

25. Hauser SL, Oksenberg JR. The neurobiology of multiple sclerosis: genes, inflammation, and neurodegeneration. Neuron. 2006; 52:61-76. [PubMed: 17015227]

26. Heaney RP, Davies KM, Chen TC, Holick MF, Barger-Lux MJ. Human serum 25hydroxycholecalciferol response to extended oral dosing with cholecalciferol. Am J Clin Nutr. 2003; 77:204-10. [PubMed: 12499343]

27. Hine TJ, Roberts NB. Seasonal variation in serum 25-hydroxy vitamin D3 does not affect 1,25dihydroxy vitamin D. Ann Clin Biochem. 1994; 31( Pt 1):31-4. [PubMed: 8154850]

28. Holick MF. Environmental factors that influence the cutaneous production of vitamin D. Am J Clin Nutr. 1995; 61:638S-645S. [PubMed: 7879731]

29. Holick MF. Vitamin D: the underappreciated D-lightful hormone that is important for skeletal and cellular health. Curr Opin in Endocrinol Diab. 2002; 9:87-98.

30. Holick MF. Vitamin D deficiency. N Engl J Med. 2007; 357:266-81. [PubMed: 17634462]

31. Kampman MT, Wilsgaard T, Mellgren SI. Outdoor activities and diet in childhood and adolescence relate to MS risk above the Arctic Circle. J Neurol. 2007; 254:471-7. [PubMed: 17377831]

32. Kurtzke JF. On the fine structure of the distribution of multiple sclerosis. Acta Neurol Scand. 1967; 43:257-82. [PubMed: 6049786]

33. Kurtzke JF. Epidemiology of multiple sclerosis. Does this really point toward an etiology? Lectio Doctoralis. Neurol Sci. 2000; 21:383-403. [PubMed: 11441577]

34. Lemire JM, Archer DC. 1,25-dihydroxyvitamin D3 prevents the in vivo induction of murine experimental autoimmune encephalomyelitis. J Clin Invest. 1991; 87:1103-7. [PubMed: 1705564]

35. Liu PT, Stenger S, Tang DH, Modlin RL. Cutting edge: vitamin D-mediated human antimicrobial activity against Mycobacterium tuberculosis is dependent on the induction of cathelicidin. $\mathrm{J}$ Immunol. 2007; 179:2060-3. [PubMed: 17675463] 
36. Mathieu C, Waer M, Laureys J, Rutgeerts O, Bouillon R. Prevention of autoimmune diabetes in NOD mice by 1,25 dihydroxyvitamin D3. Diabetologia. 1994; 37:552-8. [PubMed: 7926338]

37. Matsuoka LY, Ide L, Wortsman J, MacLaughlin JA, Holick MF. Sunscreens suppress cutaneous vitamin D3 synthesis. J Clin Endocrinol Metab. 1987; 64:1165-8. [PubMed: 3033008]

38. Matsuoka LY, Wortsman J, Dannenberg MJ, Hollis BW, Lu Z, Holick MF. Clothing prevents ultraviolet-B radiation-dependent photosynthesis of vitamin D3. J Clin Endocrinol Metab. 1992; 75:1099-103. [PubMed: 1328275]

39. Mattner F, Smiroldo S, Galbiati F, Muller M, Di Lucia P, Poliani PL, Martino G, PaninaBordignon P, Adorini L. Inhibition of Th1 development and treatment of chronic-relapsing experimental allergic encephalomyelitis by a non-hypercalcemic analogue of 1,25 dihydroxyvitamin D(3). Eur J Immunol. 2000; 30:498-508. [PubMed: 10671205]

40. Meehan TF, DeLuca HF. CD8(+) T cells are not necessary for 1 alpha,25-dihydroxyvitamin D(3) to suppress experimental autoimmune encephalomyelitis in mice. Proc Natl Acad Sci U S A. 2002; 99:5557-60. [PubMed: 11929984]

41. Munger KL, Levin LI, Hollis BW, Howard NS, Ascherio A. Serum 25-hydroxyvitamin D levels and risk of multiple sclerosis. JAMA. 2006; 296:2832-8. [PubMed: 17179460]

42. Muthian G, Raikwar HP, Rajasingh J, Bright JJ. 1,25 Dihydroxyvitamin-D3 modulates JAK-STAT pathway in IL-12/IFNgamma axis leading to Th1 response in experimental allergic encephalomyelitis. J Neurosci Res. 2006; 83:1299-309. [PubMed: 16547967]

43. Nashold FE, Hoag KA, Goverman J, Hayes CE. Rag-1-dependent cells are necessary for 1,25dihydroxyvitamin $\mathrm{D}(3)$ prevention of experimental autoimmune encephalomyelitis. J Neuroimmunol. 2001; 119:16-29. [PubMed: 11525796]

44. Panda DK, Miao D, Tremblay ML, Sirois J, Farookhi R, Hendy GN, Goltzman D. Targeted ablation of the 25-hydroxyvitamin D 1alpha -hydroxylase enzyme: evidence for skeletal, reproductive, and immune dysfunction. Proc Natl Acad Sci U S A. 2001; 98:7498-503. [PubMed: 11416220]

45. Pedersen LB, Nashold FE, Spach KM, Hayes CE. 1,25-dihydroxyvitamin D3 reverses experimental autoimmune encephalomyelitis by inhibiting chemokine synthesis and monocyte trafficking. J Neurosci Res. 2007; 85:2480-90. [PubMed: 17600374]

46. Penna G, Adorini L. 1 Alpha,25-dihydroxyvitamin D3 inhibits differentiation, maturation, activation, and survival of dendritic cells leading to impaired alloreactive T cell activation. $\mathrm{J}$ Immunol. 2000; 164:2405-11. [PubMed: 10679076]

47. Prufer K, Veenstra TD, Jirikowski GF, Kumar R. Distribution of 1,25-dihydroxyvitamin D3 receptor immunoreactivity in the rat brain and spinal cord. J Chem Neuroanat. 1999; 16:135-45. [PubMed: 10223312]

48. Pugliatti M, Sotgiu S, Rosati G. The worldwide prevalence of multiple sclerosis. Clin Neurol Neurosurg. 2002; 104:182-91. [PubMed: 12127652]

49. Rachez C, Freedman LP. Mechanisms of gene regulation by vitamin D(3) receptor: a network of coactivator interactions. Gene. 2000; 246:9-21. [PubMed: 10767523]

50. Rachez C, Lemon BD, Suldan Z, Bromleigh V, Gamble M, Naar AM, Erdjument-Bromage H, Tempst P, Freedman LP. Ligand-dependent transcription activation by nuclear receptors requires the DRIP complex. Nature. 1999; 398:824-8. [PubMed: 10235266]

51. Reichel H, Koeffler HP, Tobler A, Norman AW. 1 alpha,25-Dihydroxyvitamin D3 inhibits gamma-interferon synthesis by normal human peripheral blood lymphocytes. Proc Natl Acad Sci U S A. 1987; 84:3385-9. [PubMed: 3033646]

52. Rigby WF. The immunobiology of vitamin D. Immunol Today. 1988; 9:54-8. [PubMed: 3076760]

53. Shultz TD, Fox J, Heath H 3rd, Kumar R. Do tissues other than the kidney produce 1,25dihydroxyvitamin D3 in vivo? A reexamination. Proc Natl Acad Sci U S A. 1983; 80:1746-50. [PubMed: 6572938]

54. Spach KM, Hayes CE. Vitamin D3 confers protection from autoimmune encephalomyelitis only in female mice. J Immunol. 2005; 175:4119-26. [PubMed: 16148162]

55. Spach KM, Nashold FE, Dittel BN, Hayes CE. IL-10 signaling is essential for 1,25dihydroxyvitamin D3-mediated inhibition of experimental autoimmune encephalomyelitis. $\mathrm{J}$ Immunol. 2006; 177:6030-7. [PubMed: 17056528] 
56. Stumpf WE, Clark SA, O'Brien LP, Reid FA. 1,25(OH) 2 vitamin $\mathrm{D}_{3}$ sites of action in spinal cord and sensory ganglion. Anat Embryol (Berl). 1988; 177:307-10. [PubMed: 2833133]

57. Stumpf WE, O'Brien LP. 1,25 (OH)2 vitamin D3 sites of action in the brain. An autoradiographic study. Histochemistry. 1987; 87:393-406. [PubMed: 2828283]

58. Stumpf WE, Sar M, Clark SA, DeLuca HF. Brain target sites for 1,25-dihydroxyvitamin D3. Science. 1982; 215:1403-5. [PubMed: 6977846]

59. Sutton AL, MacDonald PN. Vitamin D: more than a "bone-a-fide" hormone. Mol Endocrinol. 2003; 17:777-91. [PubMed: 12637589]

60. Tobler A, Gasson J, Reichel H, Norman AW, Koeffler HP. Granulocyte-macrophage colonystimulating factor. Sensitive and receptor-mediated regulation by 1,25-dihydroxyvitamin D3 in normal human peripheral blood lymphocytes. J Clin Invest. 1987; 79:1700-5. [PubMed: 3034980]

61. Towers TL, Freedman LP. Granulocyte-macrophage colony-stimulating factor gene transcription is directly repressed by the vitamin D3 receptor. Implications for allosteric influences on nuclear receptor structure and function by a DNA element. J Biol Chem. 1998; 273:10338-48. [PubMed: 9553089]

62. van der Mei IA, Ponsonby AL, Blizzard L, Dwyer T. Regional variation in multiple sclerosis prevalence in Australia and its association with ambient ultraviolet radiation. Neuroepidemiology. 2001; 20:168-74. [PubMed: 11490162]

63. van der Mei IA, Ponsonby AL, Dwyer T, Blizzard L, Simmons R, Taylor BV, Butzkueven H, Kilpatrick T. Past exposure to sun, skin phenotype, and risk of multiple sclerosis: case-control study. BMJ. 2003; 327:316. [PubMed: 12907484]

64. van Etten E, Gysemans C, Branisteanu DD, Verstuyf A, Bouillon R, Overbergh L, Mathieu C. Novel insights in the immune function of the vitamin D system: synergism with interferon-beta. $\mathrm{J}$ Steroid Biochem Mol Biol. 2007; 103:546-51. [PubMed: 17254771]

65. Vieth R. Vitamin D supplementation, 25-hydroxyvitamin D concentrations, and safety. Am J Clin Nutr. 1999; 69:842-56. [PubMed: 10232622]

66. Webb AR, Kline L, Holick MF. Influence of season and latitude on the cutaneous synthesis of vitamin D3: exposure to winter sunlight in Boston and Edmonton will not promote vitamin D3 synthesis in human skin. J Clin Endocrinol Metab. 1988; 67:373-8. [PubMed: 2839537] 


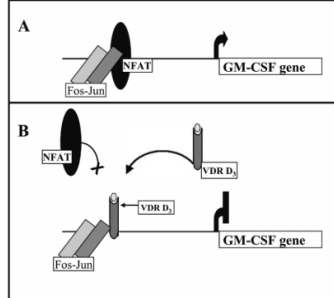

Figure 1.

Mechanism of repression of GM-CSF activated transcription by $1,25(\mathrm{OH})_{2} \mathrm{D}_{3}$. Unlike most mechanisms involved in $1,25(\mathrm{OH})_{2} \mathrm{D}_{3}$ mediated effects on transcription that require the VDR/RXR heterodimer, VDR bound to $1,25(\mathrm{OH})_{2} \mathrm{D}_{3}\left(\mathrm{VDRD}_{3}\right.$ in $\left.\mathrm{B}\right)$ acts as a monomer on the GM-CSF promoter and competes with NFAT for binding to a composite NFAT AP1 site (composite site is shown in A). VDR bound to $1,25(\mathrm{OH})_{2} \mathrm{D}_{3}$ also stabilizes the binding of Fos-Jun heterodimer by direct interaction with cJun (B). These two events result in $1,25(\mathrm{OH})_{2} \mathrm{D}_{3}$ mediated transcriptional repression of GM-CSF (Adapted from Towers and Freedman, 1998) 